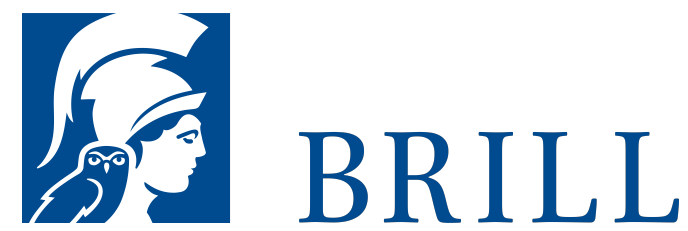

\title{
The Making of an SS Killer
}

Das Leben des Obersturmbannführers Alfred Filbert 1905-1990

Author: Alex J. Kay

In dieser wegweisenden Biografie eines Direkttäters des Holocaust deckt Alex J. Kay das Leben des SS-

Obersturmbannführers Alfred Filbert auf, der als erster Chef des SS-Einsatzkommandos 9 für die Ermordung von mehr als 18.0oo sowjetischen Juden - Männer, Frauen und Kinder - hinter der Ostfront verantwortlich war. Er zeigt, wie Filbert sich nach der politisch motivierten Inhaftierung seines älteren Bruders daranmachte, seine Treue zum NS-Regime zu beweisen, indem er bei der Umsetzung der Befehle Hitlers, Himmlers und Heydrichs besondere Radikalität an den Tag legte. Kay schildert auch Filberts Leben nach dem Krieg: sein Untertauchen, die Verhaftung, den Prozess und die Verurteilung zu lebenslangem Zuchthaus. Vorzeitig entlassen, spielte Filbert 1984 im kontroversen Spielfilm „Wundkanal“ des Regisseurs Thomas Harlan einen SS-Massenmörder - also gleichsam sich selbst. „Der eine Bruder ein Nazi-Mörder und der andere als Kommunist im Konzentrationslager: Das ist die Geschichte der Familie Filbert. Alex Kay gelingt in seinem gekonnt gearbeiteten Buch ein bedeutsamer Schritt, um Massenmorde zu verstehen, indem er die Aufmerksamkeit ebenso auf ideologische Motive wie auf die Rolle von Zufälligkeiten richtet." - Timothy Snyder „Alex Kay bereichert mit seinem Buch nicht nur die HolocaustForschung, sondern zeigt auch auf, was ein biografischer Ansatz zum Verständnis...

See More

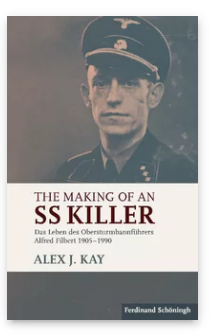

Pages: 253

Seiten, $24 \mathrm{~s} / \mathrm{w}$ Abb., 2 s/w Tab.

Language:

German

Subjects:

Modern History,

History

Publisher: Brill | Schöningh

E-Book (PDF)

Released online: o2 Sep 2019

ISBN: 978-3-

657-78693-о

List price

Hardback

Publication date: 29 Sep 2017

ISBN: 978-3506-78693-7

List price 
Alex J. Kay ist britischer Historiker mit Schwerpunkt Nationalsozialismus. Seit 2016 ist er Fellow der Royal Historical Society. Er lehrt an der Universität Potsdam.

For more information see brill.com

Order information: Order online at brill.com +44 330 333 0049 | customerservices@brill.com Submission information: brill.com/authors

Titles published by Brill | Fink, Brill | mentis or Brill | Schöningh: +49(o)71 5413279216 | brill@brocom.de 